\title{
Kelemahan Lembaga Keberatan Pajak
}

\author{
Budi Ispriyarso \\ Fakultas Hukum Universitas Diponegoro \\ budiispriyarso@ymail.com
}

\begin{abstract}
Tax disputes can occur between taxpayers or tax insurers with the government, among others because of differences in the amount of tax payable. One of the legal efforts that can be taken by taxpayers in the event of a tax dispute is an "Objection" legal effort. This objection is essentially a legal effort that is outside the Tax Court to appeal for justice in a tax dispute. The problem, what weaknesses are there in the objection institutions that exist today. Some of the weaknesses in this tax objection institution include the position within the Directorate General of Taxes or precisely a unit / part that is part of the Tax Service Office (KPP) or the Tax Office. Its position under the Directorate General of Taxation is what has caused criticism from many parties, especially with regard to independence in deciding a case, the Independent is doubtful, there is a conflict of interest. Another disadvantage is the provision that contains a "threat" to taxpayers in filing objections, namely a fine of $50 \%$ of the amount of tax payable after deducting the amount of tax paid, if the decision rejects the objection filed by the taxpayer or partially grants.
\end{abstract}

Keywords: Objection, tax dispute, taxpayer

\begin{abstract}
Abstrak
Sengketa pajak dapat terjadi antara wajib pajak atau penanggung pajak dengan pemerintah , antara lain karena perbedaan penghitungan besarnya pajak yang terutang. Salah satu upaya hukum yang dapat ditempuh wajib pajak dalam hal terjadi sengketa pajak adalah upaya hukum "Keberatan". Keberatan ini pada hakekatnya merupakan upaya hukum yang berada diluar Pengadilan Pajak untuk memohon keadilan dalam sengketa pajak. Permasalahanya, Kelemahan-kelemahan apa yang terdapat dalam lembaga keberatan yang ada saat ini. Beberapa kelemahan yang terdapat dalam lembaga keberatan pajak ini antara lain adalah kedudukannya yang berada di lingkungan Direktorat Jenderal Pajak atau tepatnya suatu unit/bagian yang merupakan bagian yang ada pada Kantor Pelayanan Pajak (KPP) atau Kanwil Pajak. Kedudukannya yang berada di bawah Direktorat Jenderal Pajak inilah yang menimbulkan kritikan dari banyak pihak khususnya berkaitan dengan keindependenanya dalam memutus suatu perkara, Keindependenanya diragukan, ada conflict of interest. Kelemahan lainnya adalah adanya ketentuan yang mengandung "ancaman" terhadap wajib pajak dalam pengajuan keberatan yaitu adanya denda sebesar $50 \%$ dari jumlah pajak terutang setelah dikurangi jumlah pajak yang telah dibayar, apabila keputusan menolak keberatan yang diajukan wajib pajak atau mengabulkan sebagian.
\end{abstract}

Kata kunci: Keberatan, sengketa pajak, wajib pajak 


\section{A. Pendahuluan}

Pajak merupakan sumber utama penerimaan negara. Tanpa pajak, kegiatan negara akan sulit untuk dilaksanakan. Pengertian pajak, tercantum dalam Pasal 1angka 1 UndangUndang Republik Indonesia Nomor 28 Tahun 2007 tentang Perubahan Ketiga Atas Undang-Undang Nomor 6 Tahun 1983 tentang Ketentuan Umum dan Tata Cara Perpajakan . Berdasarkan definisi pajak yang terdapat dalam UU KUP tersebut, dapat diketahui bahwa pajak adalah kontribusi wajib kepada negara yang terutang oleh pribadi atau badan yang sifatnya paksaan, pungutannya harus berdasarkan Undang-Undang dan tidak mendapatkan imbalan secara langsung serta digunakan untuk keperluan negara bagi sebesar-besarnya kemakmuran rakyat.

Sistem pemungutan pajak yang diterapkan saat ini, sebagian besar menggunakan sistem Self Assessment yang titik berat aktifitas perpajakan ada pada wajib pajak. Berdasarkan sistem self assessment ini, wajib pajak melakukan penghitungan sendiri besarnya pajak yang terutang dan melakukan pembayaran sendiri. Dalam prakteknya sering terjadi perbedaan penghitungan antara wajib pajak dengan fiscus tentang besarnya pajak yang harus dibayar. Hal inilah yang dapat menimbulkan sengketa pajak. Hubungan antara wajib pajak dan pemungut pajak dalam aktifitasnya memungkinkan terjadi perselisihan faham yang dapat memunculkan sengketa. ${ }^{1}$

Sengketa pajak merupakan sengketa yang timbul dalam bidang perpajakan antara wajib pajak atau penanggung pajak dengan pemerintah di bidang perpajakan. Sengketa pajak tersebut dapat dibedakan menjadi dua sengketa pajak dalam arti sempit dan dalam arti luas. Sengketa pajak dalam bentuk banding dan gugatan merupakan sengketa pajak dalam arti sempit. Sengketa pajak dalam arti luas, tidak hanya meliputi banding dan gugatan saja tetapi meliputi juga sengketa pajak yang penyelesaiannya melalui keberatan sebagai upaya hukum biasa. $^{2}$

Upaya hukum keberatan ini merupakan salah satu bentuk pelindungan hukum yang diberikan undang-undang terhadap wajib pajak apabila diperlakukan tidak adil oleh fiscus. Wajib pajak dapat melakukan upaya hukum keberatan terhadap suatu Surat Ketetapan Pajak (SKP) kepada Direktur Jenderal Pajak. ${ }^{3}$ Mengenai lembaga keberatan pajak ini, menarik

\footnotetext{
${ }^{1}$ Wiratni Ahmadi, Perlindungan Hukum Bagi Wajib Pajak Dalam Penyelesaian Sengketa Pajak, Bandung : PT Refika Aditama, 2006, halaman 50

2 Muchammad Djafar Saidi, Hukum Acara Peradilan Pajak, Jakarta : PT Raja Grafindo Persada, 2013, halaman 28.

${ }^{3}$ Fidel, Tax Law : Proses Beracara di Pengadilan Pajak dan Peradilan Umum, PT Carofin Media, halaman 27.
} 
untuk dikaji tentang kelembagaannya (kedudukanya) khususnya tentang keindependenanya. Hal lain yang perlu mendapat perhatian tentang keberatan pajak ini adalah adanya ketentuan tentang sanksi administrasi $50 \%$ dari pajak terutang apabila wajib pajak kalah dalam berperkara di lembaga keberatan pajak.. Berdasarkan hal tersebut, maka permasalahannya adalah kelemahan-kelemahan apa yang terdapat dalam pengajuan keberatan di lembaga keberatan saat ini.

\section{B. Pembahasan}

\section{Pengertian Keberatan dan Dasar Hukumnya}

Berdasarkan ketentuan undang-undang perpajakan yang berlaku saat ini, beberapa upaya hukum yang dapat ditempuh oleh wajib pajak atau penanggung pajak apabila dirugikan oleh fiscus adalah upaya hukum keberatan, banding, gugatan dan Peninjauan Kembali. Hal ini berbeda dengan di lembaga peradilan lainnya yang upaya hukumnya adalah gugatan, banding, kasasi dan peninjauan kembali. Upaya hukum keberatan merupakan upaya hukum yang penyelsesaiannya masih dilakukan di lingkungan pemerintah. Sedangkan upaya hukum banding dan gugatan merupakan upaya hukum yang penyelesaiannya (pemeriksaan dan putusannya) dilakukan di lembaga Peradilan Pajak. Lembaga Peradilan Pajak yang ada saat ini adalah Pengadilan Pajak yang dibentuk berdasarkan Undang-Undang Nomor 14 Tahun 2002 tentang Pengadilan Pajak. Kompentensi absolut Pengadilan Pajak adalah memeriksa dan memutus sengketa pajak yang berupa banding dan gugatan pajak.

Sengketa pajak dapat terjadi antara lain karena perbedaan pendapat antara wajib pajak dengan pemerintah mengenai besarnya pajak yang terutang. Berdasarkan ketentuan UU Pengadilan Pajak, khususnya dalam Pasal 1 angka 5 disebutkan bahwa sengketa Pajak merupakan sengketa yang terjadi dalam bidang perpajakan antara Wajib Pajak atau penanggung Pajak dengan pejabat yang berwenang sebagai akibat dikeluarkannya keputusan yang dapat diajukan Banding atau Gugatan kepada Pengadilan Pajak berdasarkan peraturan perundang-undangan perpajakan, termasuk Gugatan atas pelaksanaan penagihan berdasarkan Undang-undang Penagihan Pajak dengan Surat Paksa.

Berdasarkan pengertian sengketa pajak yang terdapat dalam Pasal 1 angka 5 tersebut maka dapat diketahui antara lain bahwa Pengadilan Pajak berwenang memeriksa dan memutus permohonan banding pajak sebagai akibat " keputusan yang dapat diajukan banding”. Dalam hal ini yang dimaksud "Keputusan yang dapat diajukan banding” adalah 
keputusan lembaga keberatan atas keberatan yang diajukan wajib pajak. Pengertian “ keputusan" menurut UU Nomor 14 Tahun 2002 adalah penetapan tertulis di bidang perpajakan yang dikeluarkan pejabat yang berwenang berdasarkan peraturan perundangundangan yang berlaku. Pejabat yang berwenang menurut UU pengadilan Pajak adalah Direktur Jenderal Pajak, Direktur Bea dan Cukai untuk jenis pajak pusat dan Gubernur, bupati, walikota untuk jenis pajak daerah.

Pada hakekatnya keberatan merupakan upaya hukum biasa yang berada di luar Pengadilan Pajak yang diperuntukan untuk memohonkan keadilan terhadap kerugian bagi wajib pajak. ${ }^{4}$

Pengertian keberatan adalah upaya hukum yang dapat ditempuh wajib apabila merasa tidak puas atas suatu ketetapan pajak yang dikenakan kepadanya atau atas pemotongan pajak oleh pihak ketiga.

Pemeriksaan atas keberatan yang diajukan oleh wajib pajak dilakukan oleh unit/bagian yang merupakan bagian yang ada pada Kantor Pelayanan Pajak (KPP) atau Kanwil Pajak .

Maksud diberikannya upaya hukum keberatan adalah untuk melindungi wajib pajak dari tindakan aparatur pajak yang dianggap merugikan atau dianggap tidak/kurang adil. Wajib pajak diberi kesempatan untuk mendapatkan keadilan dalam sengketa pajak melalui jalur/upaya hukum keberatan.

Dasar hukum upaya hukum keberatan diatur dalam Bab V Pasal 25 dan Pasal 26 UU Nomor 6 Tahun 1983 tentang Ketentuan Umum dan Tatacara Perpajakan sebagaimana diubah dalam UU Nomor 28 Tahun 2007. Di dalam UU Nomor 28 Tahun 2007, keberatan diatur dalam Pasal 25, Pasal 26, Pasal 26 A. Peraturan pelaksanaannya antara lain adalah Peraturan Menteri Keuangan Nomor 202/PMK.03/2015 tentang Tatacara Pengajuan Pengajuan dan Penyelesaian Keberatan .

Berdasarkan ketentuan Pasal 25 UU KUP, dapat diketahui bahwa upaya hukum keberatan dapat dilakukan oleh wajib pajak terhadap SKP KB (Surat ketetapan Pajak Kurang Bayar), SKP KBT (Surat Ketetapan Pajak Kurang Bayar Tambahan), SKP LB (Surat ketetapan Pajak Lebih Bayar), SKPN (Surat Ketetapan Pajak Nihil) dan pemotongan oleh pihak ke tiga berdasarkan ketentuan peraturan perundang-undangan perpajakan.

\section{Cara dan Syarat Mengajukan Keberatan}

\footnotetext{
${ }^{4}$ ibid, halaman 43.
} 
Ada beberapa cara yang dapat dilakukan oleh wajib pajak dalam menggunakan upaya hukum keberatan yaitu :

a. Secara langsung;

b. Melalui Pos;

c. Dengan cara lain

Pengajuan keberatan secara langsung, dilakukan dengan cara wajib pajak menyampaikan surat keberatan ke Kantor Pelayanan Pajak (KPP) tempat wajib pajak terdaftar atau tempat Pengusaha Kena Pajak dikukuhkan. Pengajuan keberatan melalui pos (kantor Pos) hendaknya dilakukan dengan bukti pengiriman surat. Pengajuan keberatan dengan cara lain, antara lain dengan menggunakan jasa ekspedisi atau jasa kurir dengan bukti pengiriman surat atau melalui on line ( e-filling).

Sebelum mengajukan keberatan, wajib pajak berhak untuk meminta keterangan secara tertulis hal-hal yang menjadi dasar pengenaan pajak, penghitungan rugi, pemotongan oleh pihak ketiga kepada dirjen pajak melalui KPP setempat. Atas permintaan keterangan ini maka Dirjen pajak wajib memberikan keterangan .

Adapun syarat untuk mengajukan keberatan adalah sebagai berikut : ${ }^{5}$

a. Keberatan harus dilakukan secara tertulis dengan menggunakan bahasa Indonesia,ditujukan kepada dirjen Pajak (untuk Pajak Pusat) melalui KPP setempat atau Gubernur (untuk Pajak Propinsi) , Bupati/Walikota (untuk Pajak Kabupaten/pajak Kota);

b. Wajib menyebutkan jumlah pajak yang terutang atau jumlah pajak yang dipotong atau dipungut atau jumlah rugi menurut penghitungan WP dan disertai alasanalasan yang jelas;

c. Satu keberatan harus diajukan untuk satu jenis dan satu tahun/masa pajak.

d. Keberatan harus diajukan dalam jangka waktu 3 (tiga) bulan sejak SKP, kecuali WP dapat menunjukan bahwa jangka waktu itu tidak dapat dipenuhi karena di luar kekuasaannya.

Keberatan yang disampaikan langsung ke KPP, maka jangka waktu 3 (tiga) bulan dihitung sejak tanggal SKPKB, SKPKBT, SKPLB, SKPN atau sejak dilakukan pemotongan/pemungutan oleh pihak ketiga sampai saat keberatan diterima oleh Kantor Pelayanan Pajak.

${ }^{5}$ www.pajak.net/info/tata_cara_pengajuan_keberatan_pajak.htm, diakses tgl 11 Mei 2019 
surat keberatan yang disampaikan melalui pos ( harus dengan pos tercatat ), jangka waktu 3 bulan dihitung sejak tanggal SKPKB, SKPKBT, SKPLB, SKPN atau sejak dilakukan pemotongan/ pemungutan oleh pihak ketiga sampai dengan tanggal tanda bukti pengiriman melalui Kantor Pos dan Giro.

e. dalam pengajuan keberatan wajib pajak harus membayar sejumlah uang tertentu paling sedikit sejumlah yang disetujui dalam pembahasan akhir hasil pemeriksaan sebelum pengajuan keberatan ; Persyaratan ini hanya berlaku untuk pengajuan keberatan atas suatu Surat Ketetapan Pajak Kurang Bayar atau Surat Ketetapan Pajak Kurang Bayar Tambahan yang berkaitan dengan Surat Pemberitahuan untuk Masa Pajak, Bagian Tahun Pajak, atau Tahun Pajak 2008 dan seterusnya.

f. Keberatan yang tidak memenuhi persyaratan di atas tidak dianggap sebagai Surat Keberatan, sehingga tidak dipertimbangkan

Disamping syarat-syarat tersebut untuk keperluan pengajuan keberatan WP dapat meminta penjelasan/ keterangan tambahan dan Kepala KPP wajib memberikan penjelasan secara tertulis hal-hal yang menjadi dasar pengenaan, pemotongan, atau pemungutan.

Apabila permohonan keberatan Wajib Pajak ditolak dan Wajib Pajak tidak mengajukan banding maka Wajib Pajak dikenai sanksi administrasi berupa denda sebesar 50\% (lima puluh persen) dari jumlah pajak berdasarkan keputusan keberatan dikurangi dengan pajak yang telah dibayar sebelum mengajukan keberatan.

Sanksi administrasi berupa denda sebesar 50\% (lima puluh persen) tidak dikenakan dalam hal:

a. Wajib Pajak mencabut pengajuan keberatan,

b. pengajuan keberatan Wajib Pajak tidak dipertimbangkan karena tidak memenuhi persyaratan pengajuan keberatan, atau

c. Wajib Pajak mengajukan permohonan banding atas Surat Keputusan Keberatan.

Atas keberatan yang diajukan wajib pajak ,Direktur Jenderal Pajak dalam jangka waktu paling lama 12 (dua belas) bulan sejak tanggal surat keberatan diterima harus memberi keputusan atas keberatan yang diajukan. Apabila jangka waktu sebagaimana dimaksud tersebut telah terlampaui dan Direktur Jenderal Pajak tidak menerbitkan Surat Keputusan Keberatan, keberatan yang diajukan Wajib Pajak dianggap dikabulkan dan Direktur Jenderal Pajak wajib menerbitkan Surat Keputusan 
Keberatan sesuai dengan keberatan Wajib Pajak dalam jangka waktu paling lama 1 (satu) bulan sejak jangka waktu 12 (dua belas) bulan tersebut berakhir. Apabila pengajuan keberatan dikabulkan sebagian atau seluruhnya, selama pajak yang masih harus dibayar sebagaimana dimaksud dalam Surat Ketetapan Pajak Kurang Bayar, Surat Ketetapan Pajak Kurang Bayar Tambahan, Surat Ketetapan Pajak Nihil, dan Surat Ketetapan Pajak Lebih Bayar yang telah dibayar menyebabkan kelebihan pembayaran pajak, kelebihan pembayaran dimaksud dikembalikan dengan ditambah imbalan bunga sebesar 2\% (dua persen) per bulan untuk paling lama 24 (dua puluh empat) bulan. ${ }^{6}$

Keputusan atas keberatan yang diajukan wajib pajak, ada 4 jenis, yaitu :

1. Mengabulkan seluruhnya;

2. Mengabulkan sebagian;

3. Menolak;

4. Menambah jumlah pajak yang masih harus dibayar

\section{Kelemahan-kelemahan Lembaga Keberatan}

Sebagaimana tersebut di atas, atas pengajuan keberatan yang diajukan wajib pajak akan diperiksa dan diputus oleh suatu unit/bagian yang merupakan bagian yang ada pada Kantor Pelayanan Pajak (KPP) atau Kanwil Pajak. Hal ini dapat dikatakan bahwa penyelesaian sengketa pajak yang berupa keberatan ini dilakukan oleh suatu unit/lembaga yang berada di bawah lingkungan Direktorat Jenderal Pajak. Tentunya hal ini, menimbulkan keraguraguan atas independensi lembaga keberatan, karena sengketa pajak ini terjadi antara wajib pajak dengan pemerintah (ditjen Pajak), tetapi yang memeriksa dan memutus adalah ditjen pajak.

Mengenai keindependensi lembaga keberatan pajak ini, banyak pihak yang memberikan kritikan/saran agar dilakukan perubahan/perbaikan tentang lembaga keberatan tersebut, karena dianggap tidak independen dan tidak efektif. Banyak keberatan yang diajukan oleh wajib pajak ditolak oleh Ditjen Pajak, sehingga harus diselesaikan oleh Pengadilan Pajak. Ditjen Pajak terkesan melemparkan tanggungjawab ke Pengadilan Pajak. Ashari Ritonga (Mantan Ketua Pengadilan Pajak) menyambut baik tentang keindependenan lembaga keberatan pajak , keberadaan lembaga keberatan yang

\footnotetext{
${ }^{6}$ https://www.ortax.org/ortax/?mod=studi\&page=show\&id=110, diakses tgl 11 Mei 2019.
} 
independen diperlukan untuk menyaring perkara pajak yang layak untuk masuk di Pengadilan Pajak. $^{7}$

Berdasarkan teori independensi kekuasaan kehakiman yang dikemukakan Jimly Asshiddiqie,bahwa independensi suatu kelembagaan dapat dilihat berdasarkan struktur organisasi. ${ }^{8}$ Berdasarkan struktur organisasi lembaga keberatan pajak yang berada dibawah Kementerian keuangan khususnya di bawah Direktorat Jenderal Pajak, maka hal ini menyebabkan ketidak independenan lembaga keberatan pajak. Apalagi sengketa pajak terjadi antara wajib pajak dengan Direktorat Jenderal Pajak, sedangkan yang menyelesaikan sengketa pajak oleh Direktorat Jenderal Pajak . Hal ini seperti Peradilan Semu (Quasi Peradilan), karena pihak yang memutus perkara merupakan salah satu pihak yang bersengketa. Keindependenanya diragukan, ada conflict of interest.

Direktorat Jenderal Pajak sendiri tengah mengkaji pemisahan divisi yang menangani keberatan pajak. Jika selama ini ditangani oleh kantor wilayah (kanwil) nantinya akan dibentuk unit baru di tingkat pusat yang khusus menangani masalah tersebut. Rencana ini akan menjadikan ditjen pajak lebih profesional, ide keberatan agar menjadi independen sudah dikaji oleh Ditjen Pajak. Artinya semi independen, artinya dibuat sendiri terpisah dari kantor pajak tetapi masih dalam lingkup ditjen pajak ${ }^{9}$. Namun demikian, ada pendapat lain, hendaknya lembaga keberatan supaya betul-betul independen, harusnya kedudukannya di luar Direktorat Jenderal Pajak.

Keberatan menjadi sangat penting mengingat proses keberatan adalah langkah mendapatkan keadilan yang pertama bagi WP. Proses Keberatan Pajak yang adil dapat meningkatkan kesadaran bagi Wajib Pajak, sehingga dengan sendirinya dapat meningkatkan kepatuhan WP. ${ }^{10}$ Mengenai persyaratan pengajuan keberatan, terdapat perkembangan mengenai pengaturannya khususnya tentang pembayaran utang pajaknya. Pada awalnya, jika wajib pajak mengajukan keberatan, maka wajib pajak tetap berkewajiban untuk membayar utang pajaknya. Ketentuan ini, dapat dilihat dalam Pasal 25 ayat (6) UU Nomor 6 Tahun 1983 yang menegaskan bahwa pengajuan keberatan tidak menunda kewajiban membayar pajak. Ketentuan ini dimaksudkan untuk mencegah

\footnotetext{
7 https://www.ortax.org/ortax/?mod=berita\&page=show\&id=6800\&q=\&hlm=402, diakses tanggal 20 Januari 2019

${ }^{8}$ Tim Peneliti Komisi Yudisial, Pengawasan Hakim Pengadilan Pajak Oleh Komisi Yudisial, Jakarta : Komisi Yudisial, halaman 31.

${ }^{9}$ Hantriono Joko Susilo, Direktur Transformasi Proses Bisnis Ditjen Pajak, 6 Juni 2018 ,Kontan Co.id 7Juni 2018.

${ }^{10}$ Devi Purnamasari, “Analisis Implementasi Prinsip Keadlan Dalam Proses Penyelesaian sengketa Keberatan Pajak Pada Direktorat Jenderal Pajak", Jurnal Reformasi Administrasi, Vol.3,No.1, Maret 2016, halaman 86
} 
usaha penghindaran atau penundaan melalui surat keberatan, yang dapat menganggu penerimaan negara dari sektor perpajakan.

Dalam perkembangannya, terdapat perubahan persyaratan dalam pengajuan keberatan, setelah dikeluarkannya UU Nomor 28 Tahun 2007 tentang perubahan ke tiga UU Nomor 6 Tahun 1983 tentang KUP (Ketentuan Umum Perpajakan. Perubahan tersebut dicantumkan dalam Pasal 25 ayat 3 a , yang menyatakakan dalam hal Wajib Pajak mengajukan keberatan atas surat ketetapan pajak, Wajib Pajak wajib melunasi pajak yang masih harus dibayar paling sedikit sejumlah yang telah disetujui Wajib Pajak dalam pembahasan akhir hasil pemeriksaan, sebelum surat keberatan disampaikan.

Perubahan ini dimaksudkan untuk memperbaiki ketentuan sebelumnya yang menentukan bahwa pengajuan keberatan tidak menunda kewajiban membayar pajak yang dapat diartikan bahwa wajib pajak harus tetap melunasi utang pajaknya terlebih dahulu meskipun sedang mengajukan keberatan. Ketentuan ini dianggap kurang adil, karena belum ada keputusan terhadap keberatan yang diajukan, wajib pajak dipaksa untuk membayar utang pajaknya sesuai yang ditetapkan dalam SKP. Oleh karena itu untuk memperbaiki ketentuan tersebut, diubah wajib pajak tidak perlu membayar semuanya, tetapi membayar paling sedikit sejumlah yang disetujui wajib pajak dalam akhir pemeriksaan. Menurut penulis, ketentuan ini masih juga dirasa belum adil, karena ada kewajiban wajib pajak untuk membayar utang pajaknya (meskipun hanya sebagian) sebelum adanya keputusan atas keberatan yang diajukannya. Seharusnya pembayaran utang pajak, dibayar setelah ada keputusan dirjen Pajak. Hal ini juga tidak sesuai dengan asas peradilan yang sederhana, cepat dan biaya ringan seperti yang tercantum dalam UU Nomor 48 Tahun 2009 tentang Kekuasaan kehakiman khususnya Pasal 2 ayat (4).

Beberapa ketentuan lainnya, yang dirasa tidak adil adalah ketentuan yang terdapat dalam Pasal 25 angka 9, Pasal 25 angka 10 dan Pasal 27 angka 5 d.

Pasal 25 angka 9 yang menyatakan Dalam hal keberatan Wajib Pajak ditolak atau dikabulkan sebagian, Wajib Pajak dikenai sanksi administrasi berupa denda sebesar 50\% (lima puluh persen) dari jumlah pajak berdasarkan keputusan keberatan dikurangi dengan pajak yang telah dibayar sebelum mengajukan keberatan.

Selanjutnya Dalam Pasal 25 angka 10, disebutkan bahwa dalam hal Wajib Pajak mengajukan permohonan banding, sanksi administrasi berupa denda sebesar 50\% (lima puluh persen) sebagaimana dimaksud pada ayat (9) tidak dikenakan. 
Dalam Pasal 27 angka 5 d, disebutkan bahwa dalam hal permohonan banding ditolak atau dikabulkan sebagian, Wajib Pajak dikenai sanksi administrasi berupa denda sebesar 100\% (seratus persen) dari jumlah pajak berdasarkan Putusan Banding dikurangi dengan pembayaran pajak yang telah dibayar sebelum mengajukan keberatan.

Berdasarkan ketentuan di atas, terlihat bahwa wajib pajak yang akan berperkara di lembaga keberatan pajak, diancam dengan denda yang cukup besar yaitu sanksi administrasi berupa denda sebesar $50 \%$. Adanya ancaman ini tentunya dapat menimbulkan "ketakutan" bagi wajib pajak untuk mengajukan upaya hukum keberatan, karena biayanya sangat tinggi apabila sampai kalah di lembaga keberatan. Akhirnya kemungkinan banyak wajib pajak yang mengurungkan niatnya untuk mengajukan keberatan, karena adanya sanksi tersebut. Apalagi apabila wajib pajak kalah di lembaga keberatan, kemudian mengajukan banding, ancamannya lebih menakutkan lagi, dendanya menjadi $100 \%$ apabila permohonan bandingnya ditolak. Ketentuan ini menurut penulis dari aspek keadilan kurang adil karena wajib pajak pada posisi yang lemah.

Ketentuan ini juga tidak sesuai dengan asas equality before the law (asas kesamaan di depan hukum) karena ada perbedaan perlakuan antara pihak yang bersengketa. Harusnya ketentuan tentang ancaman denda $50 \%$ untuk keberatan yang ditolak maupun $100 \%$ untuk banding pajak yang ditolak, ini dihilangkan, walaupun pajak mempunyai fungsi budgeter, namun jangan mengabaikan aspek keadilan.

\section{Simpulan}

Berdasarkan uraian di atas, dapat disimpulkan bahwa kelemahan yang terdapat dalam lembaga keberatan yang ada saat ini, antara lain adalah kedudukannya yang berada di bawah lingkungan Direktorat Jenderal Pajak, Sehingga diragukan keindependenanya dalam memutus suatu perkara dikhawatirkan ada conflict of interest. Kelemahan lainnya,adalah adanya ketidak adilan dalam berperkara di lembaga keberatan pajak. Hal ini dapat dilihat dalam ketentuan yang terdapat dalam UU KUP, yang mencantumkan adanya sanksi membayar denda $50 \%$ dari jumlah pajak yang terutang, jika keberatan wajib pajak ditolak atau dikabulkan sebagian. Hal ini dapat menimbulkan rasa "ketakutan" wajib pajak untuk mengajukan keberatan, karena resiko /ancaman berupa dendanya cukup tinggi. 
Agar lembaga keberatan pajak menjadi lembaga yang independen, kedudukannya tidak berada di dalam lingkungan Direktorat Jenderal Pajak, sebaiknya berada di luar Direktorat Jenderal Pajak. Disamping itu, perlu dilakukan perubahan (penghapusan) ketentuan yang mencantumkan adanya sanksi denda administrasi $50 \%$ apabila wajib pajak ditolak atau dikabulkan sebagian d, agar tidak menimbulkan rasa "ketakutan" bagi wajib pajak untuk mencari keadilan dalam sengketa pajak di lembaga keberatan pajak.

\section{Daftar Pustaka}

Ahmadi,Wiratni, Perlindungan Hukum Bagi Wajib Pajak Dalam Penyelesaian Sengketa Pajak, Bandung : PT Refika Aditama, 2006

Fidel, Tax Law : Proses Beracara di Pengadilan Pajak dan Peradilan Umum, PT Carofin Media, 2014.

Peraturan menteri Keuangan Nomor 202/PMK.03/2015 tentang Tatacara Pengajuan Pengajuan dan Penyelesaian Keberatan .

Purnamasari, Devi, "Analisis Implementasi Prinsip Keadlan Dalam Proses Penyelesaian sengketa Keberatan Pajak Pada Direktorat Jenderal Pajak", Jurnal Reformasi Administrasi, Vol.3,No.1, Maret 2016

Saidi, Muhammad Djafar,2013, Hukum Acara pengadilan Pajak, Jakarta, PT Raja Grafindo Persada

Susilo, Hantriono Joko, Direktur Transformasi Proses Bisnis Ditjen Pajak, 6 Juni 2018 ,Kontan Co.id 7 Juni 2018

Tim Peneliti Komisi Yudisial, Pengawasan Hakim Pengadilan Pajak Oleh Komisi Yudisial, Jakarta : Komisi Yudisial,2015.

Undang-Undang Nomor 14 Tahun 2002 tentang Pengadilan Pajak

Undang-Undang Nomor 28 Tahun 2007 tentang Perubahan Ketiga UU Nomor 6 Tahun 1983 tentang Ketentuan Umum dan Tata Cara Perpajakan 